Original Research Paper

\title{
Pelatihan Penulisan dan Penyuntingan Karya Ilmiah bagi Guru-Guru MTS dan MA Pondok Pesantren Azziziyah Kapek di Kecamatan Gunungsari Kabupaten Lombok Barat
}

\author{
Hamidsyukrie $\mathrm{ZM}^{1 *}$, Muntari ${ }^{1}$, A.Wahab Jufri ${ }^{1}$ \\ ${ }^{1}$ Program Studi Magister Administrasi Pendidikan, Pascasarjana Universitas Mataram
}

*Corresponding Author:

Hamidsukrie ZM, Program Studi Magister Administrasi Pendidikan, Pascasarjana Universitas Mataram, Indonesia;

Email:

hamidsyukrie@yahoo.com

\begin{abstract}
Abstrak: Salah satu kompetensi yang wajib dipenuhi guru adalah kompetensi profesional. Dalam melaksanakan pengembangan keprofesian berkelanjutan, guru harus mampu melakukan publikasi ilmiah hasil penelitian atau gagasan dalam bidang ilmu pendidikan. Karya tulis bisa berupa laporan di antaranya hasil penelitian pendidikan, makalah ilmiah, tulisan ilmiah popular, artikel ilmiah dalam bidang pendidikan, dan buku teks pelajaran. Tujuan pengabdian kepada masyarakat kali ini adalah agar guru memahami secara komprehensif mengenai teknik penyusunan karya ilmiah; guru terampil dalam menyusun karya tulis ilmiah untuk publikasi; dan guru bisa mempublikasikan tulisan ilmiahnya dalam jurnal ilmiah. Metode yang digunakan dalam pengabdian kepada masyarakat ini adalah melalui pelatihan atau training yang lebih berbasis pada praktek yang didasarkan pada tagihan dan kebutuhan guru. Pengabdian dilaksanakan dengan tahapan sebagai berikut: studi literatur, menganalisis kebutuhan guru, pengukuran kemampuan awal guru, mendesain kurikulum pelatihan, pelaksanaan pelatihan berupa kajian teori, praktek membuat karya tulis ilmiah untuk dipublikasikan, pemantauan dan bimbingan di lapangan, evaluasi hasil pelaksanaan pelatihan, dan penyusunan laporan. Hasil kegiatan pelatihan menunjukkan bahwa kegiatan pelatihan penulisan karya ilmiah sangat dibutuhkan oleh guru. Hal ini didasarkan pada pengakuan guru dan hasil evaluasi kegiatan. Selain itu, berdasarkan penilaian terhadap artikel yang disusun setelah kegiatan pelatihan, guru belum mampu membuat tulisan yang layak untuk dipublikasikan pada jurnal ilmiah nasional.
\end{abstract}

Kata Kunci: pelatihan, penulisan, penyuntingan, karya ilmiah

\section{Pendahuluan}

Kompetensi profesionalisme guru merupakan hal yang penting yang harus dimiliki seorang guru. Artinya guru harus mampu melaksanakan dan mengembangkan profesinya. Bagi guru yang mampu menunaikan tugas dan mengembangkan profesinya diberi penghargaan dengan satunya adalah kenaikan pangkat/ golongan yang diikuti dengan kenaikan gaji. Pengembangan profesi dengan kenaikan pangkat/ golongan Iva ke atas menuntut sedikitnya 12 angka kredit, namun fakta yang terjadi di lapangan ternyata membuat karya tulis ilmiah ini merupakan kegiatan yang tidak mudah dilakukan khususnya guru SD dan SMP. Para guru PNS di itngkat pendidikan dasar dan menengah sulit mencapai pangkat di atas IVa, karena kemampuan mereka membuat karya tulis ilmiah (KTI) masih lemah, padahal membuat KTI menjadi salah satu syarat kenaikan pangkat. Dari data Badan Kepegawaian Nasional (BKN) 2005, sekitar 1,4 juta guru berstatus PNS (Chotimah, 2011) umumnya berada di pangkat III/A samapai III/D yang jumlahnya mencapai 996.926 guru. Adapun di golongan IV, ada 336.601 guru, dengan rincian golongan IV/A sebanyak 334.184 guru, golongan IV/B berjumlah 2.318 guru, golongan IV/C sebanyak 84 guru, dan golongan IV/D ada 15 guru. Membuat karya tulis ilmiah merupakan salah satu upaya yang dapat dilakukan oleh guru dalam mengembangkan profesinya, disamping karyakarya yang lain. 
Mengingat pentingnya peranan guru dalam memajukan pendidikan nasional dan menyiapkan sumber daya manusia yang berkualitas, guru yang berkualitas di masa sekarang dan yang akan datang mutlak diperlukan. Untuk itu, pemerintah melalui Menteri Negara Pendayaan Aparatur Negara mengeluarkan Permenegpan Nomor 16 Tahun 2009 tentang jabatan angka fungsional guru dan angka kreditnya. Unsur dan sub unsur kegiatan guru yang dinilai angka kreditnya meliputi pendidikan, pembelajaran/ pembimbingan, pengembangan keprofesian berkelanjutan, dan penunjang. Pengembangan profesi berkelanjutan meliputi sub unsur pengembangan diri, publikasi ilmiah, dan karya inovatif. Publikasi ilmiah dapat meliputi publikasi ilmiah atas hasil penelitian atau gagasan inovatif pada bidang pendidikan formal dan publikasi buku teks pelajaran. Pada Pasal 16 Ayat (2) dinyatakan bahwa "Untuk kenaikan jabatan/ pangkat stingkat lebih tinggi dari guru pertama, pangkat penata muda, golongan ruang IIIa sampai dengan guru utama, pangkat pembina utama, golongan ruang IVe wajib melakukan kegiatan pengembangan keprofesian berkelanjutan yang meliputi sub unsur pengembangan diri, publikasi ilmiah, dan/atau karya inovatif."

Kegiatan ilmiah bagi guru berupa: (1) presentasi pada forum ilmiah, publikasi ilmiah atas hasil penelitian atau gagasan ilmu di bidang pendidikan formal, publikasi buku pelajaran, buku pengayaan, dan pedoman guru (Djuroto dan Suprijadi, 2003). Tingkat kerajinan guru dalam publikasi ilmiah, merupakan kriteria guru masa depan, yaitu terampil dalam menulis KTI untuk publikasi. Rajin menghasilkan karya tulis ilmiah (diligent to produce scientific writing). Menulis merupakan aktivitas melatih berpikir logis, sistematis, argumentatif, penggunaan bahasa, dan lain-lain. Semua kemampuan yang dibutuhkan dalam kegiatan menulis tersebut sangat mendukung profesi guru, baik dalam proses belajar-mengajar maupun dalam berdiskusi dan memecahkan masalah pembelajaran. Guru juga sewajarnya berfungsi sebagai pembimbing dalam pelaksanaan karya tulis ilmiah bagi murid-muridnya. Berbagai pembaruan dalam pelaksanaan proses pembelajaran yang berintikan kemandirian dalam belajar menuntut agar siswa-siswanya mampu membuat karya ilmiah. Keterampilan tersebut tentunya sangat mendukung adanya program life skill yang tengah digalakkan di dunia pendidikan.
Kesulitan dalam proses penulisan akibat ketidakmampuan menulis guru dapat mengakibatkan frustasi yang disertai dengan perilaku bermacam-macam. Dalam kenyataannya, ada guru yang mogok menulis karena bingung apa yang harus dikerjakan. Dengan banyaknya dampak negatif yang dapat ditimbulkan dari kesulitan menulis, maka tampaknya persoalan ini tidak bisa dibiarkan berlarut-larut. Bagaimanapun persoalan kesulitan menulis tidak hanya berhubungan dengan pengumpulan angka kredit melalui penulisan karya ilmiah, tetapi berkaitan juga dengan kualitas proses pembelajaran di sekolah. Bisa dibayangkan bagaimana kualitas lulusan dihasilkan dalam hal menulis, apabila gurunya sendiri tidak mampu menulis.

Faktor-faktor penyebab kesulitan guru yang dikemukakan di atas masih bersifat umum. Tentu saja masih banyak faktor lain yang mungkin menghambat guru dalam menulis, misalnya: Pertama, guru kurang membaca. Kegiatan membaca dapat dikatakan sebagai faktor kunci dalam menulis. Kedua, guru kurang latihan menulis. Belajar menulis sama halnya dengan belajar berenang; kalau tidak dipraktikkan tidak akan pernah bisa berenang. Ketiga, guru kerancuan dalam berpikir. Faktor ini sering sekali terjadi sehingga tulisan kelihatan kacau dan tidak jelas alur logika yang digunakan (Djuroto dan Suprijadi, 2003).

Untuk dapat menyelesaikan masalah yang dihadapi para guru SMP di Kecamatan Gunung Sari Kabupaten Lombok Barat, maka salah satu solusinya adalah dengan cara memberikan pelatihan pada para guru sekolah menengah pertama yang berbasis pada praktek dan pembimbingan in service trainingbagi guru-guru SMP di Kecamatan Gunung Sari Kabupaten Lombok Barat.

Kemampuan penulisan karya tulis ilmiah adalah sesuatu yang harus dipelajari dan dimiliki oleh seorang guru. Hal ini penting karena terkait dengan persyaratan kenaikan pangkat ke jenjang yang lebih tinggi yang menuntut adanya karya tulis ilmiah. Keluhan banyak guru pada saat ini adalah sulitnya kenaikan pangkat/ golongan terutama untuk mencapai golongan IVa ke atas. Untuk mencapai golongan yang dimaksud, seorang guru harus memiliki karya tulis ilmiah yang terpublikasikan dalam jurnal ilmiah. Salah satu faktor yang menghambat guru menulis adalah 
rendahnya pengetahuan dan kemampuan menulis karya ilmiah.

Tujuan pengabdian dengan kegiatan pelatihan ini adalah agar: 1) Guru memiliki pengetahuan dan keterampilan dalam penulisan karya ilmiah, 2) Guru mampu menulis dan menyunting karya tulis ilmiah, 3) Guru mampu membuat dan mempublikasikan karya tulis ilmiah pada jurnaljurnal ilmiah.

Manfaat yang diperoleh guru dari kegiatan pelatihan ini adalah: 1) Guru dapat memiliki pengetahuan dan keterampilan penulisan karya tulis ilmiah. 2) Guru dapat melaksanakan dan mengembangkan keterampilan penulisan karya tulis ilmiah. 3) Guru dapat menyusun karya tulis ilmiah yang memenuhi syarat ilmiah untuk dipublikasikan.

\section{Metode Pelaksanaan}

Metode yang digunakan pada pengabdian ini adalah pelatihan yang berbasis praktik penyusunan karya tulis ilmiah dengan pembimbingan intensif. Peserta diberi pemahaman tentang dasar-dasar, prinsip-prinsip, dan model penulisan karya tulis ilmiah. Peserta dibekali pengetahuan penulisan ilmiah mulai dari penggunaan bahasa yang baik dan benar, penulisan kalimat topik dan pengembangan paragraph, membuat parafrase, penulisan rujukan dan kutipan, plagiarisme, sistematika dan unsurunsur penulisan karya tulis ilmiah. Pelatihan penulisan paragraph sangat penting dalam karya tulis ilmiah (Hamidsyukrie ZM, 2003). Guru selanjutnya ditugaskan untuk memilih suatu topik dan mengembangkannya dalam bentuk karya tulis ilmiah. Setelah guru menyelesaikan penulisan, tim mereviu, mengoreksi dan mengembalikannya kepada para guru untuk diperbaiki sehingga dapat menghasilkan karya tulis ilmiah yang layak untuk dipublikasikan.

Salah satu solusi yang ditawarkan adalah pemberian pengetahuan dan pelaksanaan pelatihan bagi guru-guru SMP yang ada di Kecamatan Gunung Sari Lombok Barat. Sebelum pelaksanaan pelatihan, tentu saja tim pelaksana pengabdian melakukan brainstorming dengan para guru agar diperoleh informasi yang tepat dan komprehensif tentang kebutuhan mendesak yang diperlukan guru dalam menulis karya ilmiah. Hal ini penting dilakukan karena dengan cara ini tim pengabdian dapat memahami dan mengembangkan penulisan karya ilmiah melalui pelatihan yang intensif sehingga pada akhirnya seorang dapat menghasilkan karya tulis ilmiah yang memenuhi kriteria ilmiah.

Target luaran kegiatan pelatihan penulisan karya ilmiah pada guru-guru ini adalah: 1) Guru mampu mengaplikasikan pengetahuan dan keterampilan dalam menyusun karya tulis ilmiah. 2) Guru mampu menyusun karya tulis ilmiah yang memenuhi standar ilmiah sehingga dapat dipublikasikan dalam jurnal ilmiah. 3) Kegiatan pengabdian ini menghasilkan karya tulis ilmiah yang dipublikasikan pada jurnal ilmiah nasional.

\section{Hasil dan Pembahasan}

Kegiatan pelatihan penulisan karya ilmiah bagi guru-guru SMP Negeri di Kecamatan Gunung Sari Lombok Barat menunjukkan hasil yang baik. Hal ini diindikasikan oleh hal-hal berikut: 1) Guru-guru peserta pelatihan sangat antusias terhadap kegiatan pelatihan. Hal ini ditunjukan dengan keterlibatan sekolah dengan mengirim guru-guru sebagai peserta pelatihan. Selain itu, kepala sekolah terutama kepala sekolah SMPN 3 Gunung Sari yang bersedia menyiapkan tempat pelatihan. 2) Selama kegiatan pelatihan berlangsung, banyak peserta yang mengajukan pertanyaan, pandangan, permintaan bimbingan, dan harapan agar kegiatan semacam ini dapat dilanjutkan dengan pembingan dan pendampingan sehingga peserta dapat menghasilkan tulisan yang baik dan benar. 3) Selama kegiatan berlangsung, para peserta sangat tekun mendengarkan, mencatat, berlatih, dan mengkomunikasikan kembali yangsudah disampaikan oleh tim pengabdian, serta menyampaikan hambatan yang mereka hadapi ketika menulis karya ilmiah. 4) Para peserta menyampaikan kesan, penilaian, dan pandangan bahwa kegiatan pelatihan penulisan karya ilmiah sangat bermanfaat bagi guru-guru untuk meningkatkan kompetensi akademik dan profesionalisme guru. Dalam hal ini menurut mereka, guru-guru terbantu terutama untuk kenaikan kepangkatan, karena tulisan ilmiah merupakan salah satu syarat untuk bisa diangkat ke pangkat/golongan yang lebih tinggi.

Ada beberapa faktor pendukung yang menentukan kesuksesan kegiatan ini. Faktor-faktor 
itu adalah sebagai berikut: 1) Adanya kebutuhan guru-guru untuk diberikan pelatihan penulisan karya ilmiah. 2) Kemampuan penulisan ilmiah para guru SMPN yang masih kurang yang diindikasikan oleh kurangnya tulisan guru pada jurnal-jurnal ilmiah lokal /nasional. 3) Adanya keinginan para guru dan kepala sekolah untuk dapat menyusun tulisan ilmiah yang dapat dimuat dalam jurnal ilmiah nasional / terakreditasi nasional.

Faktor-faktor yang menghambat kegiatan pelatihan adalah sebagai berikut: 1) Waktu kegiatan yang terbatas. Hal ini berdampak pada terbatasnya kegiatan yang dapat dilakukan, terutama dalam praktik penulisan. 2) Para peserta sulit memulai menulis karena takut salah dan sulit menemukan topik-topik yang menarik dan faktual. 3) Meskipun banyak peserta yang tampak semangat dalam mendiskusikan permasalahan yang dihadapi dalam penulisan karya ilmiah, namun ada juga yang tampak sulit mengemukakan permasalahannya.

\section{Kesimpulan}

Kegiatan pengabdian pada masyarakat dengan tema pelatihan penulisan karya ilmiah secara umum dianggap berhasil yang dibuktikan oleh hasil yang dicapai selama dan setelah kegiatan berlangsung, yaitu: 1) Adanya semangat para peserta dan kepala sekolah dalam menyambut dan mengikuti kegiatan pelatihan. 2) Adanya kesan, pengalaman, dan pandangan para peserta bahwa kegiatan ini sangat bermanfaat bagi guru-guru terutama dalam upaya kenaikan pangkat / golongan.

\section{Saran}

Saran yang dapat dikemukakan dari kegiatan pelatihan penulisan karya ilmiah adalah sebagai berikut: 1) Bagi Dikpora Lombok Barat agar dapat melaksanakan kegiatan sejenis pada guru-guru di semua level pendidikan agar mereka terbiasa menyampaikan gagasannya melalui bahasa tulis. 2) Bagi sekolah agar dapat melakukan kegiatan sejenis bagi guru-guru yang ada sekolahnya. 3) Kegiatan semacam ini dapat dilakukan dengan cara berkolaborasi dan bekerja sama dengan Universitas Mataram, mulai dari proses kegiatan sampai dengan penerbitan produknya pada jurnal-jurnal ilmiah yang relevan (jurnal kependidikan) terutama yang ada di FKIP Universitas Mataram.

\section{Daftar Pustaka}

Chotimah, U. 2011. Karya Ilmiah sebagai Salah Satu Karya Pengembangan Profesi. Jakarta: PT. Bina Karya.

Djuroto, Totok dan Bambang Suprijadi. 2003. Menulis Artikel \& Karya Ilmiah. Bandung: Remaja Rosda Karya.

Hamidsyukrie ZM. 2003. Writing Paragraph. Mataram: FKIP Universitas Mataram.

Peraturan Pemerintah Nomor 32 Tahun 2013 tentang Standar Nasional Pendidikan.

Pemendiknas Nomor 16 Tahun 2007 tentang Standar Kualifikasi Akademik dan Kompetensi Guru.

Undang-Undang Nomor 20 Tahun 2003 tentang Sistem Pendidikan Nasional.

Undang-Undang Nomor 14 Tahun 2005 tentang Guru dan Dosen.

Universitas Negeri Malang. 2000. Pedoman Penulisan Karya Ilmiah: Skripsi, Artikel, dan Makalah Edisi Keempat. Malang: Universitas Negeri Malang. 